\title{
Gold Mineralisation in Chigargunta Area of the Kolar Schist Belt, South India- A Part of the Archean Greenstone Belt
}

\author{
Debasish Roy \\ Retired Director, G.S.I, Kolkata, INDIA
}

Email address:

roydebasish51@gmail.com

\section{To cite this article:}

Debasish Roy. Gold Mineralisation in Chigargunta Area of the Kolar Schist Belt, South India- A Part of the Archean Greenstone Belt. Earth Sciences. Special Issue: Archean Metallogeny and Crustal Evolution. Vol. 4, No. 4-1, 2015, pp. 40-46.

doi: $10.11648 /$ j.earth.s.2015040401.14

\begin{abstract}
Gold mineralisation is reported for the first time in 'Champion gneiss' (quartzo-feldspathic schist) a felsic unit,in the eastern sector of the Chigargunta area (Lat: $12^{0} 43^{0} 30^{\circ} \mathrm{N}$, Long: $78^{0} 15^{\circ} 00^{\circ} \mathrm{E}$ ) of the Kolar schist belt, South India, during 1979-80. Quartzo-feldspathic gneiss and hornblende schist are the predominant rock types of the area. These rocks are characterised by a strong pervasive foliation trending $\mathrm{N} 5^{\circ} \mathrm{E}-\mathrm{S} 5^{0} \mathrm{~W}$ to $\mathrm{N} 20^{\circ} \mathrm{E}-\mathrm{S} 20^{\circ} \mathrm{W}$ with easterly dips of $70-85$. In the northern part of the area the rocks are folded with the foliation which is axial planar. Lower to middle amphibolite facies metamorphism is widespread in the area. Gold mineralisation is localised along shear zones which are ductile to brittle in nature. These zones are parallel to subparallel to the trend of foliation in the host rock and are characterized by strong mylonitic fabric, profuse quartz venation and hydrothermal alteration. Pyrite and pyrrhotite are the dominant sulphides. Gold occurs in native form. This felsic hosted gold mineralisation termed as E-2 lode (for exploration purpose) is estimated to contain a reserve of 3.13 million tonnes averaging 4.7 $\mathrm{g} / \mathrm{t}$ gold. Besides, this lode there are several loads ( E-1,E-3, etc) occur within mafic units as well as in felsic unit adjacent to E-2 lode with different reserves, within the schist belt. Epigenetic gold mineralisation shows a close temporal and spatial relationship to late Archean (2700-2500 m.y) crustal accretion, stabilisation and granulite formation in the South Indian Shield. The present work delineate, the nature of mineralization in felsic unitwithin the schist belt which was not considered as source rock of gold mineralization during the period and left untouched until the present work.
\end{abstract}

Keywords: Archean, Gold, Champion Gneiss, South India

\section{Introduction}

The late Archean (3000 m.y to 2500 m.y) is a significant gold metallogenic epoch in all the major Archean shield areas of the world (Cameron [1]).

The Kolar Greenstone Belt in Karnataka is comparable with the greenstone belt, of South Africa, Canada and Western Australia, The geology, structure and the nature of mineralisation in all these belts, are quite similar.

The predominance of mafic volcanics, absence of basal conglomerates, negligible sedimentary intercalations, migmatized intrusive margins and the presence of diapiric plutons along the margins are characteristics of this belt. The Kolar Schist Belt covers a $3-6 \mathrm{~km}$ wide area extending up to $80 \mathrm{~km}$ in length. The rocks within the belt comprise complexly folded and faulted mafic and felsic volcanic sequence generally of low metamorphic grade. The Archean schistose rock, of Dharwar, in the South Indian shield record a large number of gold occurrences but gold is being produced from only three eastern belts, at Kolar, Ramgiri and Hutti ( Fig-1) with an average metal $(\mathrm{Au})$ content of about 1000 tonnes based on pre- mining reserve. Among these three the total metal content of Kolar far outweighs the other two.

The northern $40 \mathrm{~km}$ long portion of the belt has laterite cover restricts exploration work. (Fig-2.) . The southern 40km long belt inlcudes the known deposit; Kolar Gold Mine, and newly discovered Chigargunta deposit fall in the southern tip of the belt ' $\mathrm{K}$ '(Fig.1) which has been geologically mapped by a team of the Geological Survey of India during 1979-84 (Fig. $2 \& 3)$.

There are numerous gold occurrences and prospects within South Kolar schist belt. Most of the gold mineralization occurs near to the contact of the metabasalt (amphibolite) with felsic volcanic, and metasediments of the Champion Gneiss. The zone is in places highly sulphidic and at one of the prospects; molybdenite is a significant constituent of the mineralization.

Gold is preferentially concentrated in vein quartz, often 
associated with sulphides. Most of these gold prospects represent typical Archean hydrothermal lode gold mineralisation(Ridley et.al[3])The Mallapokanda gold deposit is hosted within sulphidic banded iron formation.(Fig.3.) (Mukherjee,M.M[9]), Gold mineralization is hosted by hornblende schist in the western part of the schist belt, whereas in the eastern part mineralisation occurs in the felsic volcanic of the Champion Gneiss. Mineralization is controlled by shear zones which transect the north south trending regional schistosity at low angles, generally with a north-northeast orientation.

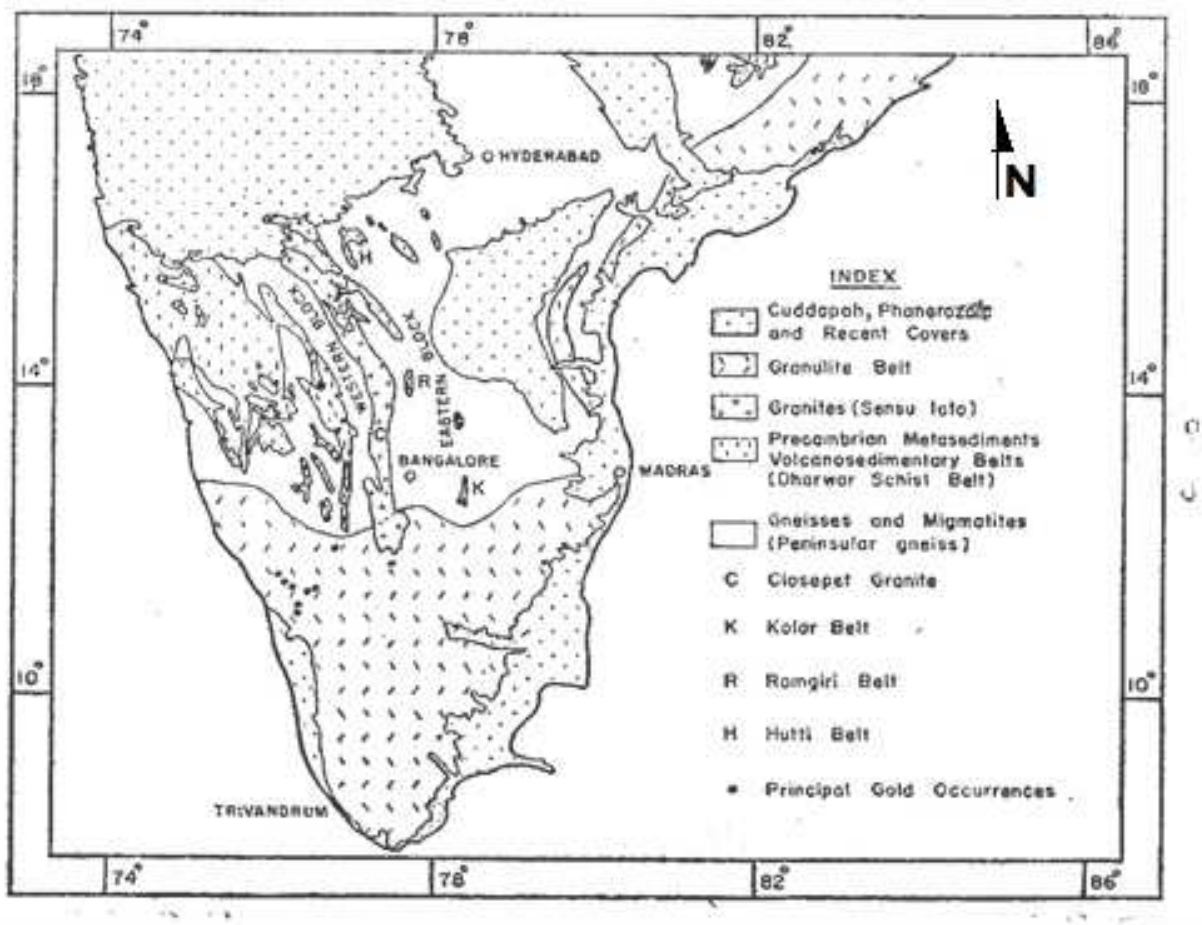

Fig. 1. Outline geological map of South Indian shield. (After Narayanaswami, S., [2]).
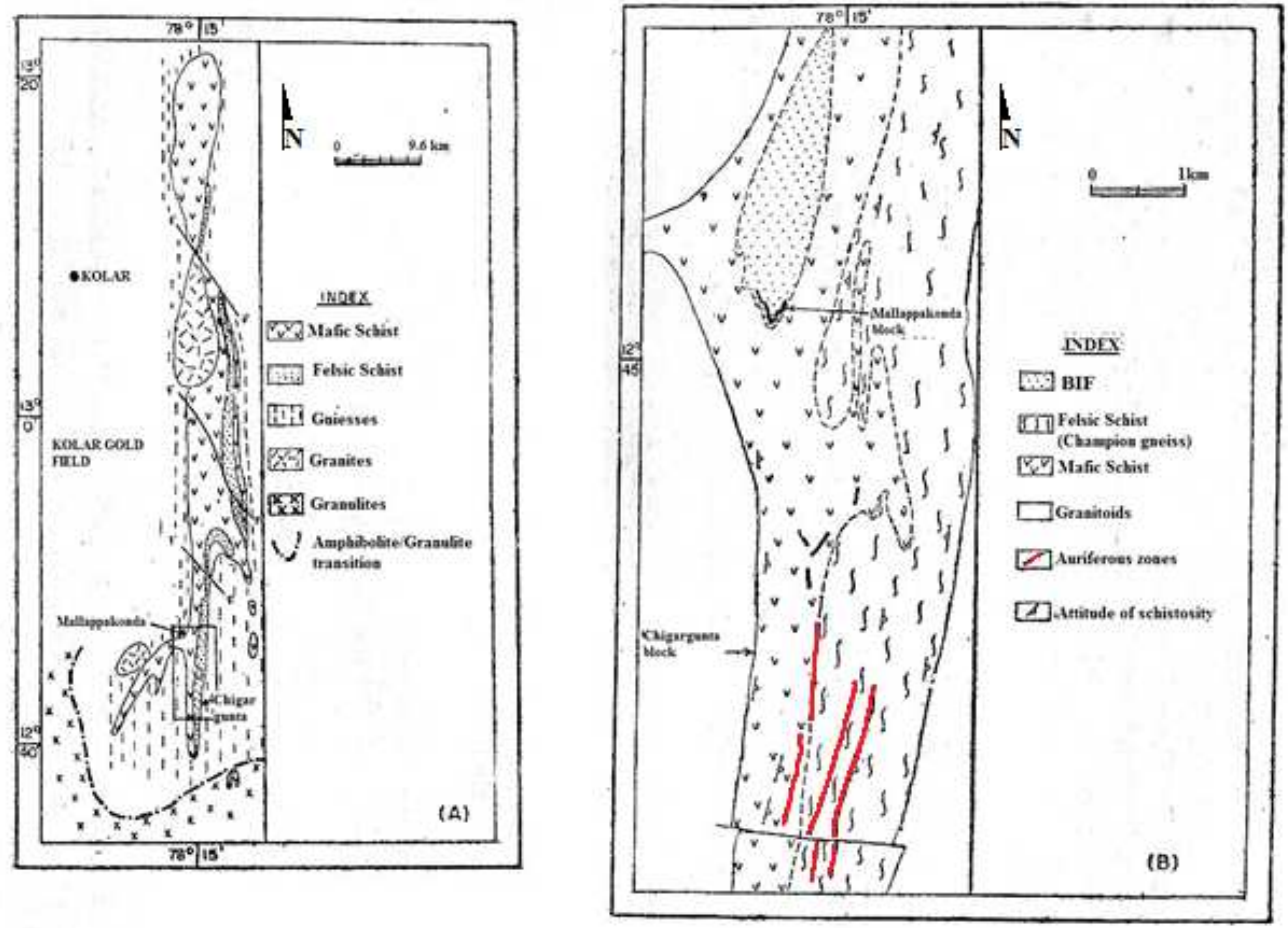

Fig. 2. Outline geological map of the Kolar schist belt (A) and southern part of Kolar schist belt (B), (demarcated in A). (After Mukherjee,M.M[9], (Shashidharan,K., Roy, Debasish.[8]). 


\section{Regional Geology}

The Kolar schist belt hosting gold mineralisation of the Kolar gold fields (KGF) is one of the richest gold mineralised area $\{>800$ tonne $\mathrm{Au}$, (Mining Annual Review, Kolar Gold Field), amongst the Archean green stone belt, of the world. The long, linear Kolar belt measuring about $400 \mathrm{sq} \mathrm{km}$ is made up of supratcrustal rock comprising metamorphosed basic lava, acid lavas, tuffs, banded iron formation (BIF),graphitesulphide schist and polymict conglomerate ( Narayanaswami et.al,[4]), These can broadly be classified in to three distinct lithounits, i.e.i) mafic schist, ii) felsic rocks ( Champion gneiss) and iii) BIF and graphite -sulphide schist in order of abundance. The rocks belong to the Archean Kolar Group of the Dharwar Super group in the South Indian Shield. The generalized stratigraphy is given in Table-1.

Table 1. Generalised stratigraphy of the South Indian Shield (After Naqvi, [5]).

\begin{tabular}{ll}
\hline $\begin{array}{l}\text { Proterozoic rocks (Cuddapahs, Kaladgi, } \\
\text { Badami,etc.) }\end{array}$ & Unconformity \\
\hline Younger granites (Closepet,etc), & $(2500 \mathrm{Ma})$ \\
$\begin{array}{l}\text { Dharwar Supergroupa) Chitradurga groupb) } \\
\text { Bababudan/ Kolar group }\end{array}$ & $(2900-2600 \mathrm{Ma})$ \\
Peninsular Gneiss & $(3300-2900 \mathrm{Ma})$ \\
Sargur Group/ Holenarasipur Group & $(>3000 \mathrm{Ma})$ \\
\hline
\end{tabular}

The Kolar schist belt is about $80 \mathrm{~km}$ in length in N-S direction and has a maximum width of about $6 \mathrm{~km}$ in the middle part. Fig-3. The mafic schist is the dominant rock type occupying the western portion of the schist belt. It comprises metamorphosed basalt (pillowed), gabbro and pyroxenite now represented by hornblende schist, amphibolite and ultramafic schist. The felsic rock, known as 'Champion gneiss' occur, all along the eastern margin of the schist belt. This is a heterogeneous assemblage of volcano sedimentary rock. The volcanic component is represented by rhyolite,rhyodacite to dacite flows and tuffs. The sedimentary assemblage consists, of greywacke-arkose with interbanded polymict conglomerate, sulphidic chert and finer clastic, with tuffaceous admixer. BIF and graphitic sulphide schist are the least abundant rock unit, occurring as thin bands within the mafic unit and felsic unit. However the occurrence of such bands in felsic unit is much less.

This assemblage has formed tight isoclinal fold with axial surface trending in N-S direction and steep dip towards east.They have suffered regional low pressure green schist to amphibolite facies metamorphism and are migmatised along the borders. (Swaminath and Ramakrishnan,[6])

Recent radiometric dating of the amphibolite (mafic unit) by (Hanson et al. [7]) gave Sm-Nd age of $2690 \pm 140 \mathrm{Ma}$. The gneissic rock occurring to the east and west of the schist belt yields ages of $2532 \mathrm{Ma}$ to $2633 \mathrm{Ma}( \pm 10 \mathrm{Ma})$ by by $\mathrm{U}-\mathrm{Pb}$ method. The zircons in the gneiss occurring to the west of the schist belt have inherited cores, at least 3200Ma old (Hanson et al, [7]). The above line of evidence broadly indicate that the Kolar schist belt rocks are ensialic and are slightly older than the adjoining granitoid.

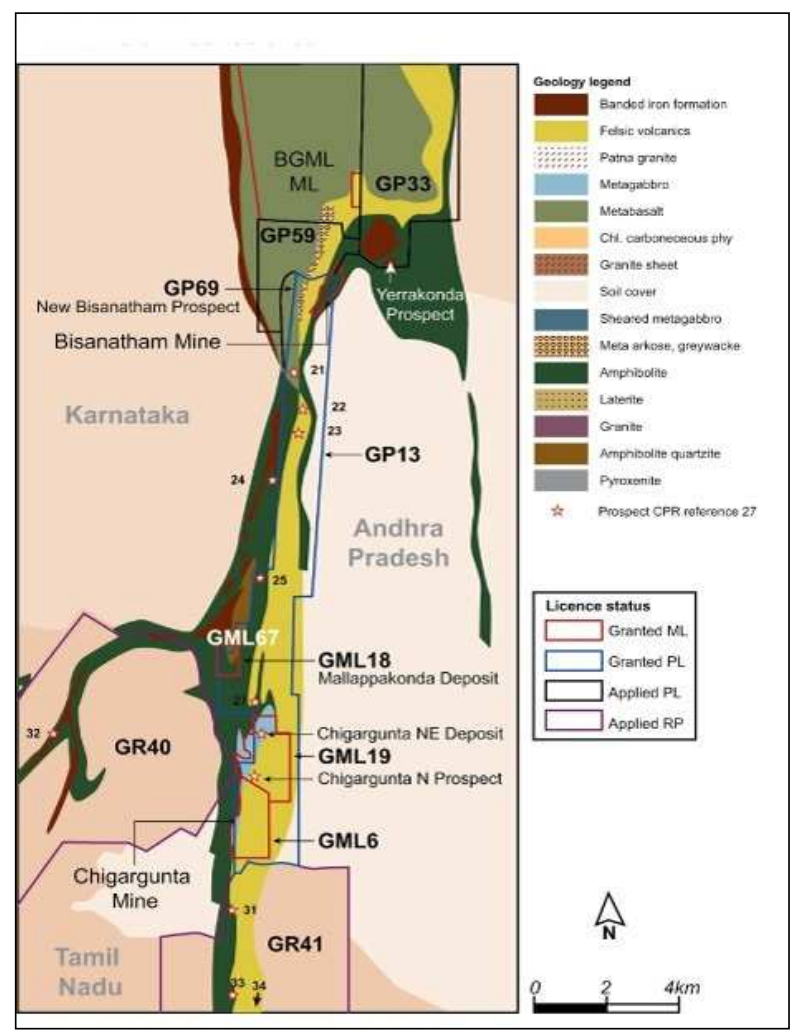

Fig. 3. Southern part of (KolarSchist belt ' $K$ ' in Fig.1) Chigargunta Gold Prospect within felsic unit. Showing licence boundaries and nos. of different blocks.

The general trend of the foliation in the schist belt varies from N-S to NNE-SSW with westerly and easterly dips of $60^{0}-85^{0}$. The rocks are folded into a doubly plunging synform and metamorphosed into a greenschist to amphibolite facies.

\section{Geological Characteristics of Host Rock Champion Gneiss in Chigargunta Area}

In Chigargunta area Champion gneiss and hornblende schist constitute the predominant rock types. (Fig.2) The felsic unit (Champion gneiss) which is about 800-1000 $\mathrm{m}$ in width occupies the eastern half of the south Kolar schist belt.(Fig.2) It is typically a coarse, inequigranular, strongly foliated rock with large (up to a few $\mathrm{cm}$ in diameter) polycrystalline glomeroblast of plagioclase, K-feldspar, biotite, quartz and quartz-feldspar myrmekite. (Shashidharan,K., Roy,Debasish., Mukherjee,M.M,.[8])

At places,there are embayed grains of quartz and plagioclase. These larger quartz, feldspar and aggregate grains are set in a finer grained mosaic of similar quartzo-feldspathic composition with mica, chlorite and occasional hornblende. The rock is believed to represent a metamorphosed tuff and on an $\mathrm{Al}_{2} \mathrm{O}_{3}-\mathrm{SiO}_{2}$ binary diagram (Fig-5) the plots conform closely to the average dacite. Two narrow bands of ultramafic 
schist occur one in the Champion gneiss and other in hornblende schist. Of these, the one in the Champion gneiss occur parallel to the foliation of the country rock whereas, the other in the hornblende schist occurs at an oblique angle to the foliation in hornblende schist. (Shashidharan,K., Roy,Debasish. Mukherjee,M.M[8]). The mafic unit of the schist belt occur mainly to the western portion (fig-2A,2B and 3 ). It is represented by metamorphosed basalt ( hornblende schist, amphibolite) with minor bodies of metagabbro and metapyroxenite. The intercalation of felsic unit (Champion gneiss ) is common within the hornblende schist. Major element chemistry of the 10 analyzed samples from the mafic schist are ploted mainly in the tholeiitic basalt field (Fig-4) A dolerite dyke, 10 to $30 \mathrm{~m}$ in width trending N-S to $N 5^{\circ} \mathrm{E}$ to $\mathrm{S} 5^{0} \mathrm{~W}$ is seen in the central part of the Champion gneiss. A number of pegmatite and quartz veins transect the country rock. The pegmatite are tourmaline bearing and a majority of these trend in a NNE-SSW direction. The champion gneiss is a leucocratic well foliated, coarse to medium grained rock. It is a hybrid rock comprising acid volcanics, metabasic rocks and metasediments. All these components are intimately associated and are extensively modified by hydrothermalactivities which renders them difficult to delineate while mapping. The acid volcanics are rhyolite to dacite in composition. The metabasic rocks occur as narrow bands parallel to sub parallel to the foliation. These may represent older dykes intruding the acid volcanics and the sedimentaries which have been subsequently metamorphosed. The sedimentary rocks are arkose and quartzite. Some major oxide plots of the mafic schist in the southern part of the Kolar schist belt in Jensen calion diagram (after Charan et.al [10]) are given in( Fig. 4.)

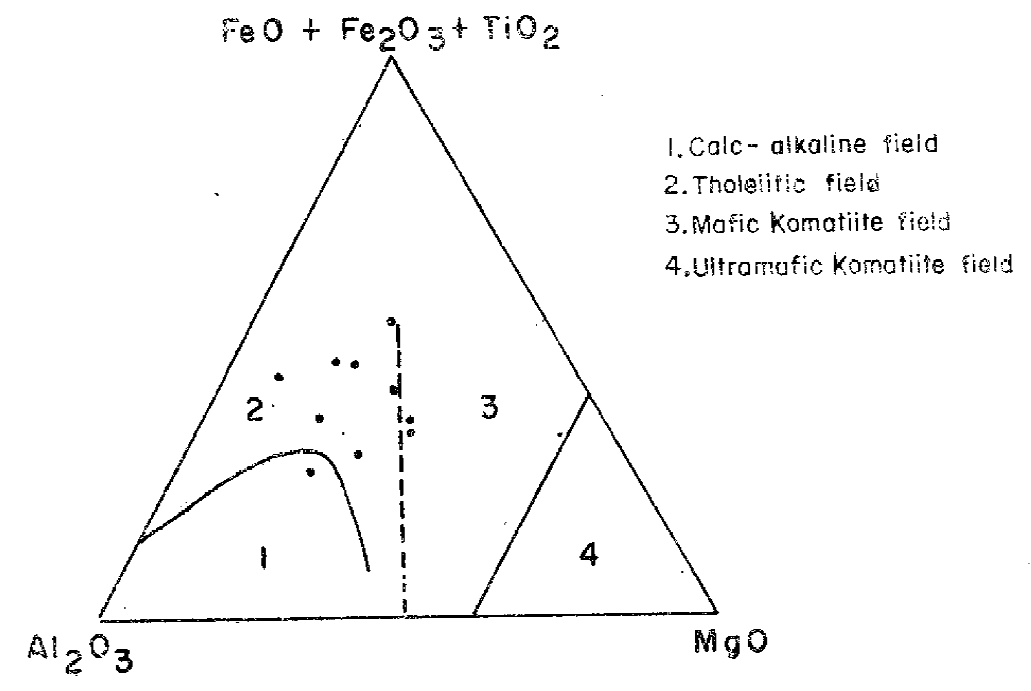

Fig. 4. Some major oxide plot of the mafic schist in the southern part of the Kolar schist belt in Jensen calion diagram (after Charn et.al [10]).

The different components that constitute the Champion gneiss have given rise to distinct mineral assemblages. Staurolite, quartz. feldspar and sericite 1 are the typical assemblageof sedimentary parentage. Though these rocks show effect of granitisation, however rounded clasts of quartz are seen under microscope indicating there clastic sedimentary character. Inquartzite quartz is the principal component with minor amount of muscovite and sericite. The acid volcanics have quartz, plagioclase, muscovite and biotite as the major minerals. They frequently exhibit porphyroblastic texture. The porphyroblasts are polycrystalline aggregate of either quartz + feldspar or quartz + feldspar + biotite. The feldspar include both microcline and plagioclase. The plagioclase is mostly oligoclase or albite. The matrix has also a similar composition consisting of quartz, feldspar, biotite and sericite. Tourmaline and sphene are ubiquitous. Secondary biotite, fluorite, calcite and sericite occur in significant quantities in all the sub-units of the Champion gneiss indicating hydrothermal alteration.

The metabasites in the Champion gneiss contain amphiboles (namely actinolite and hornblende) and plagioclase. The amphiboles show frequent alteration to biotite. The ultramafic schist which occur as narrow bands consists of olivine, actinolite and tremolite. Some relic pyroxene grains are still present. Magnetite occur as accessory. Parent rock appears to be peridotite. (Shashidharan,K., Roy, Debasish., Mukherjee,M.M[8])

The Champion gneiss as in the case of mafic schist are charecterised by a number of parallel shear zones of varying extensions. These are zones of high deformation transecting the country rocks at narrow angles or running parallel to the country rock foliation, postdating the first deformation. These shear zones are ductile to brittle in nature and are mineralised in varying magnitude. In the shear zones the shapes of the equidimensional mineral components and minerals aggregates show significant changes. The mineral aggregates show reduction of grain size and a preferred orientation. Quartz shows evidence of plastic behaviour, characterised by undulose extension and feldspars show kinks. Plenty of brittle fracture are evident. As the fabric strengthens towards the centre of the shear zone (into a zone of higher deformation) the fabric lines become closer forming a mylonite. Besides 
flattened porphyroblasts showing a constant orientation, permanent strain effect in the rocks are also seen as an extension failure,filled mostly with quartz and mica. These openings generally make an angle of $30^{\circ}-40^{\circ}$ with with the shear planes showing a sigmoidal form.

Besides these, shear zones that transect the country rocks at high angles are also noticed. These shear zones show ductile deformation and have developed large permanent strain, often without the development of specific surfaces of rupture. These are much latter and devoid of mineralisation.A prominent fault trending ENE-WSW is noticed towards the northern part (Fig $2 \mathrm{~A} \& 2 \mathrm{~B})$. This fault with a dextral shift displaces all the lithounits and the shear zones. It is charecterised by a wide zone of fracturing,silicification, epidotization and brecciation. The mineral assemblage of the rocks of Chigargunta area are indicative of a lower to middle amphibolite facies metamorphism(Shashidharan,K., Roy, Debasish. Mukherjee, M.M [8]). The Champion gneiss shows an assemblage of

a) Quartz + plagioclase + orthoclase + microcline + biotite + muscovite + sericite.

b)Quartz + feldspar + staurolite + biotite + garnet.

In hornblende schist the mineral assemblage is

a) Hornblende + epidote + oligoclase + almandine + sphene

b) Hornblende +actinolite+ albite +epidote +quartz

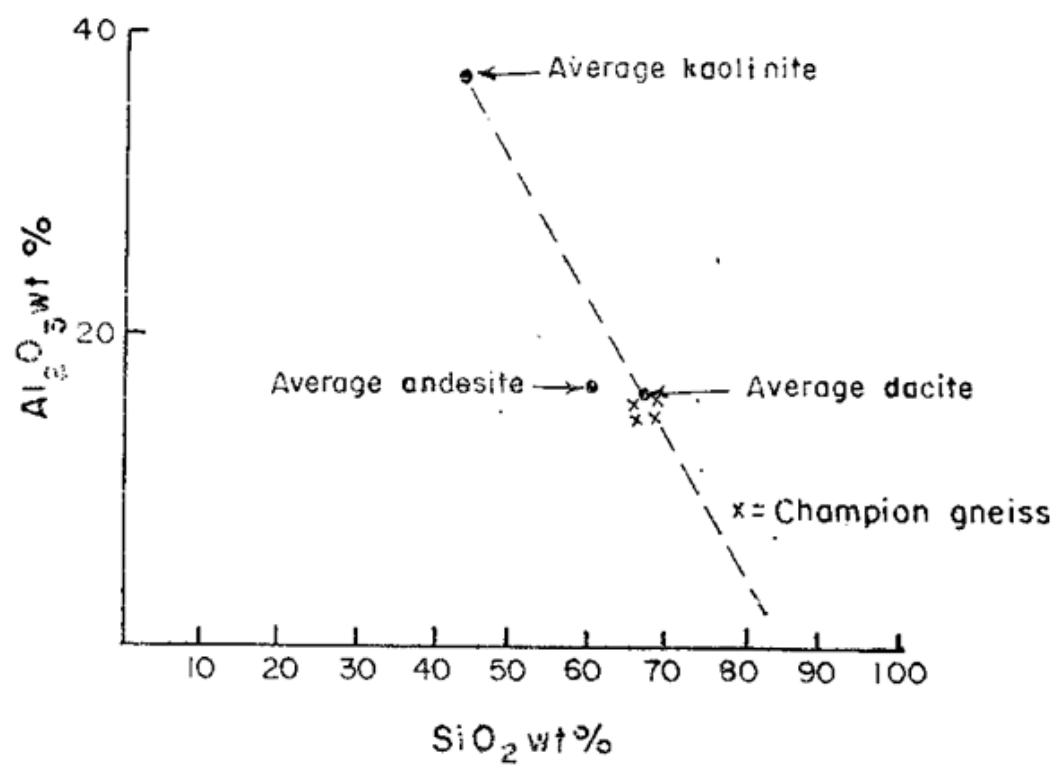

Fig. 5. $\mathrm{SiO}_{2}-\mathrm{Al}_{2} \mathrm{O}_{3}$ plot of the 'Champion gneiss' in the southern part of the Kolar schist belt. (After Stanton [11]).

\section{Gold Mineralisation and Crustal Evolution}

The Kolar schist belt, one of the auriferous Archean schist belt in the Dharwar craton,includes two types of gold deposit : 1) a stratiform sulphide type, associated with amphibolites and banded ferrugineous quartzite and 2) a gold quartz carbonate vein type associated with LREE- enriched komatiitic and tholeiite amphibolite on the eastrn part of the belt (Sivasiddaiah and Rajamani,[12])

Gold mineralisation in the Chigargunta area is localised along zones of high deformation which are ductile to brittle in nature and occur over a strike length of $3 \mathrm{~km}$ in Chigargunta area (Fig 2b). Though shear zones of different orientation are seen, only those which have a near parallel relationship to the foliation of the country rock are found to be mineralised. Those that transect the foliation at high angles are much younger,ductile in nature and are barren of mineralisation.

The mineralized shear zones are characterised by a strong mylonitic foliation and profuse hydrothermal alteration. Significant changes in grain size and texture are observed in the champion gneiss in proximity to shear zone. Major changes in silicate mineralogy and texture in and around the shear zone reflect the onset of extensive hydrothermal alteration that accompanied mineralization. Sericitization, biotitisation, silicification, tourmalization, flourtization and carbonatization are the noticeable wall rock alteration. Biotitization is the main alteration noticed in the mineralised zone. The biotite thus formed is honey brown colour. Fibrolite development is seen in the feldspar of Champion gneiss which in turn is sericitised. Tourmaline occurs as tiny prism, pale greenish brown to black in colour showing an orientation parallel to shear zones foliation. Presence of fluorite, tourmaline and scapolite in abundant quantites in the mineralised rock indicate that the hydrothermal solution were rich in volatiles like $\mathrm{F}, \mathrm{Cl}$ and $\mathrm{B}$. Presence of appreciable quantities of mica, some of them lilac brown coloured, coarse along with fluorite, tourmaline suggest a greisening effect.

Quartz occurs as veins, veinlets and pods parallel to the shear zone foliation and appears to be liberated from wall rock. Pegmatite and granitic materials are also seen as veins and pods within the mineralized zone. Those granitic veins frequently follow zones with high gold values. Hornfelsic 
texture is very much evident in the mineralized zone, because of the introduction of new materials probably at moderately high temperature.

Pyrite and pyrrhotite are the dominant sulphides present in the mineralized zones. They occur mainly in disseminated form in the Champion gneiss hosted mineralization. Frequently pyrite dissemination are seen for considerable width in the wall rock of the Champion gneiss.

In the mafic hosted mineralisation the proportion of sulphides are found to be more. Pyrrhotite is the dominant sulphide along with pyrite. Pyrrhotite sometimes occur, in massive form. Aresenopyrite, chalcopyrite, galena, sphalerite and stibnite are noticed in minor quantities. Galena is always associated with high gold values.Gold occur in native form within quartz stringers, pods and veins.

From the available evidence it is apparent that gold emplacement took place in two stages in southern part of the Kolar schist belt. The sulphidic BIF are auriferous in many places showing high back ground gold values (about $100 \mathrm{ppb}$ ). It is likely that this interflow sediments got deposited in similar fashion to the ones which are forming around present day oceanic spreading centre (Seibold and Berger,[13]). The association of pillowed tholeiite lavas with the auriferous BIF and the presence of minor subvolcanic basic intrusives with post-peak metamorphic mineral assemblage described earlier, are strong indication for such a process to have been operative. In the ore zone, native gold has also been found as finely disseminated grains within arsenopyrite. (Mukherjee,M.M.,[9]). The second stage of gold mineralisation is epigenetic and shows an independent tectono-metamorphic evolution postdating the major folding and regional amphibolite facies metamorphic event. Auriferous zones are confined to discrete ductile shear zones where large scale retrogression of the silicate and quartz-sulphide-gold mineralisation occurred as a result of wide spread introduction of hydrous fluid. The spatial association of some acid porphyries within and close to the mineralised shear zones and the hydrothermal alteration of the host rocks point towards an acid magmatic source for the ore fluids. However, the tonalite-trondjhemite-granodiorite suit of Peninsular gneiss outside the schist belt was formed earlier than the major tectonic evolution of the Kolar schist belt. Immediately to the south of the Kolar schist belt, there is a transition zone where extensive migmatisation of high grade supracrustal rocks have taken place (Condie and Allen, [14]. Further south of the transition zone, progressive metamorphism of gneisses, mafic and sedimentary enclaves to granulites by dehydration and $\mathrm{CO}_{2}$ streaming along $\mathrm{N}-\mathrm{S}$ trending shear zone at about $2500 \mathrm{Ma}$ has been indicated (Gopalakrishnan et al,[15] )

\section{Acknowledgement}

Author acknowledges Dr.M.M. Mukherjee, K. Shashidarwan and W.K. Natarajan for fruitful discussion/suggestions during field work. Author also acknowledges Dr. T.K. Baidya, Professor, Geological Sciences, Jadavpur University for fruitful discussion and valuable suggestions.

\section{References}

[1] Cameron,E.M 1988. Archean Gold: Relation to Granulite formation and Redox Zoning in the crust. 16(2), 109-112

[2] Narayanaswami, S., 1963. The gold fields of India. Geol.Soc.Ind.Mem,. 1, 39-48

[3] Ridley,et.al., 1990. Wall rock alteration in amphibolite facies gold deposit. University of Western Australia, Publication 20, 79-86

[4] Narayanaswami, S., Ziauddin,M and Ramachandra, A.V., 1960 . Structural Control and Localisation of Gold-Bearing lode, Kolar Gold Fields, India. Econ.Geol, 55, 1429-1459

[5] Naqvi, S.M., 2005: Geology and Evolution of the Indian plate (From Hadean to Holocene 4Ga to $4 \mathrm{Ka}$ ) Capital Pub. Co. (New Delhi), 2005, 10-56

[6] Swaminath, J. and Ramkrishna,M., 1981. Early Precambrian Supracrustals of Southern Karnataka.Mem.Geol.Surv.Ind. 112, 221-245

[7] Hanson,G.N., Krogstad,E.F,. and Rajamani,V., 1988. Tectonic Setting of the Kolar Schist Belt,Karnataka, India (Abstract) J.Geol. Soc. Ind, 31,40-42.

[8] Shashidharan, K. Roy. Debasish, Mukherjee, M.M.and Natarajan, W.K., 1987. A Report On The Investigation for Gold in 'Champion Gneiss' Chigurgunta, (Blocks III,II,I) Eastern Sector, Chittoor District, Andhra Pradesh (F.S.P. 1983-84). Unpublished Report. Southern Region, Geological Survey of India

[9] Mukherjee, M.M., Evolutionary aspect of Gold Mineralisation in Southern part of Kolar Schist Belt, Indian Minerals, $43,(3 \& 4), 347-360$.

[10] Charan,S.N., Naqvi, S,M and Ramesh,S.L. 1988, Geology and Geochemistry of Spinifex-Textured Peridotite Komatiite from Mayasandra Schist Belt, Karnataka. J.Geol. Soc. Ind, $32,343-350$

[11] Stanton,R.L.,1976 Petrochemical studies of the ore environment at Broken Hill, New South Wales, Tr. Inst. Min. Metal, 85(B), 221-233

[12] Siva Siddaiah, N. and Rajamani, V,. 1989: The Geologic setting, mineralogy,Geochemistry and genesis of gold deposits of the Archean Kolar Schist Belt, India. Econ. Geol., 84, 2155-2172.

[13] Seibold,E and Berger, W.H 1982. The sea floor. Springer-Verlag, Berlin,244

[14] Condie,K.C and Allen,P., 1984. Origin of Archean Charnockites from Southern India. In 'Archean Geochemistry'- The Origin and Evolution of the Archean Continental crust, Springer-Verlag, 161-181

[15] Gopalakrishnan,D.,Hansen,E.C, Janardhan,A.S and Newton, R.C., 1986 The southern high grade margin of Dharwar Craton J Geol., 94, 247-260.. 